\title{
Modeling the Religious Field: Religion, Spirituality, Mysticism, and Related World Views
}

\author{
HEINZ STREIB AND RALPH W. HOOD \\ Research Center for Biographical Studies in Contemporary Religion, \\ Universität Bielefeld \\ Psychology Department, University of Tennessee at Chattanooga
}

Heinz.Streib@uni-bielefeld.de; Ralph-Hood@utc.edu

\begin{abstract}
Mapping the religious field of present-day Western cultures such as America and Europe requires a synopsis of perspectives. There are, on the one hand, classical ways of defining religion in theology, sociology and psychology, and also established sociological models of the religious field; and there are, on the other hand, recent changes in how people on the street implicitly and explicitly understand themselves and behave. Many are reluctant to identify as religious persons, but self-identify as "spiritual" or "spiritual, not religious." In this text we introduce our conceptualization of religion and of the religious field. Key concepts of religion are transcendence and ultimacy. For structuring the religious field, we attend to the distinction between vertical and horizontal symbolization of transcendence and ultimacy, and to the distinction between institutional mediation and individual immediacy.
\end{abstract}

\section{Keywords}

spirituality, mysticism, religion, religious field, Bourdieu

The increase in the use of the self-description, as being "spiritual," and even "spiritual, but not religious," can be taken as an indication of a major change in the religious landscape (Hood 2003). Many scholars declare "spirituality" rather than "religion" as the object of their theorizing and empirical research, suggesting that spirituality may replace religion as a dominant motif in the religious field (Houtman and Aupers 2007). We see this as a problem insofar as it risks ignoring the roots of a more than a century-long discourse on religion, which has been a major object of study in the early days of both sociology and psychology. Therefore, as 
argued in previous texts (Streib and Hood 2011), we will step back and focus on the concept of religion in classical conceptualizations, in order to aid understanding of the contemporary religious field. Our intent is not to seek a unidirectional interpretative movement and simply go to the classics and apply them to the contemporary situation. Rather, it is in fact a two-directional interpretation: Contemporary changes in religiosity also suggest revisions and modifications of the classics. Thus in this text we want to both reinstate and reinterpret the classics, in order to understand the contemporary religious field.

For constructing a model of the religious field for America and Europe, two key questions can be stated, as follows: First, what concept of religion is inclusive, but precise enough, for understanding and analyzing contemporary religiosity, spirituality and related world views? Second, how can we come to terms with the drift from the churches, i.e. account, in an up-todate model of the religious field, for the emigration of religiosity, spirituality and related world views from organized religion? So, we will explain in some detail both our conceptualization of religion and our model of the religious field. Key concepts in our model are transcendence and ultimacy. We will explicate why it is helpful to ground a concept of religion on these components. In a second step, our model of the religious field will be introduced, focusing upon a distinction between vertical and horizontal symbolization of transcendence and ultimacy, and a distinction between individual immediacy and institutional mediation.

\section{Conceptualizing "religion"}

For conceptualizing religion and defining its basic elements, we suggest starting with and focusing on the most elementary experiential and structural characteristics, rather than on a plentitude of substantive or functional characteristics. This does not mean that we disregard or oppose substantive (e.g. divine beings; supernatural agents) or functional (e.g. complexity reduction; coping with contingencies and anxiety; social integration) characteristics, but we suggest regarding them as secondary and putting them on hold, in order to bring the elementary to the foreground. Such a starting point, with the basic experiential and structural elements, corresponds well with psychology, because its object is the individual, or, more specifically: individual experiences, beliefs, attitudes and commitments in their relation to behavior and action in the social environment. From such a central position of the individual, for which we may (e.g.) refer to W. James (1902/1985), our focus is on individual religiosity, and the reli-

(C) Equinox Publishing Ltd. 2013

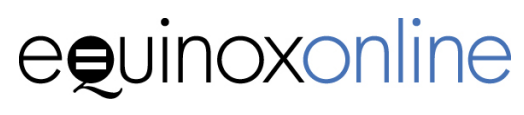


gious individual as actor in the religious field. For our approach therefore it may be adequate to use conceptual markers for "religion" which are verblike and describe the experiences, attitudes and activities of the individual.

In psychology, the sacred has served as an influential definitional marker for religion and spirituality (Pargament 1997; Zinnbauer, Pargament and Scott 1999; Zinnbauer and Pargament 2005). Because, in most of these contributions, the concept of the sacred oscillates between the human activity of "sacralizing"-which indeed is verb-like-and the assumption of a reality out there that we call the sacred, it may be adequate to look for alternatives. Methodological agnosticism implies that we refrain from any presupposition of a supernatural world or sacred realm, while remaining open to the fact that individuals may be viewed as not only involved in a search for, or the imagination of, the supernatural or sacred, but may also be viewed as responding to the supernatural or sacred, especially when the focus is upon religious experience (James 1902/1985; Otto 1917/1958). It is on the basis of this tradition that we propose two characteristics for conceptualizing religion.

\section{Transcendence and ultimacy as key characteristics of "religion"}

Our key concepts for religion are transcendence and ultimacy. For "transcendence," we refer to the social-phenomenological tradition of A. Schütz (1989) and T.Luckmann (1967; 1991; cf. Knoblauch 1991). For "ultimacy" we refer to the concept of ultimate concern in P.Tillich's $(1925 ; 1951 ; 1957)$ philosophy of religion. Both transcendence and ultimacy have a verb-like character: transcendence refers to "transcending the everyday world," and ultimacy to be committed and "to be ultimately concerned." The experience of transcending only secondarily finds its way into symbolization and into the social construction of reality, i.e. in the dimension of beliefs. Thus we find it useful to distinguish an immediate experience from what is subsequently an elaborate interpretation of experience, which is associated with religion as both belief and institutionalization or the social constructions associated with religious experience (Hood 2006; Hood, Hill and Spilka 2009, Chs. 10, 11). Both concepts (transcending and being ultimately concerned) are necessary and complement each other.

Transcending everyday reality is possible in a variety of ways and directions. As suggested by Schütz (1989, 117-130) and Luckmann (1991, 164-182), "great" transcendences occur in sleep and dream, in daydreaming and ecstasies, in crises and death and finally in theoretical orientations. Thereby, it would be a misunderstanding to take any kind of "great"

(C) Equinox Publishing Ltd. 2013

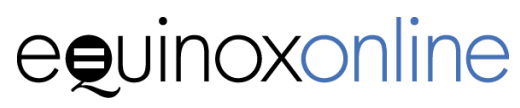


transcendence as religion. On the contrary, this conceptual approach to religion is based on the process of transcending in various provinces of the life-world. Which experiences of transcendence are associated with religion, depends on the symbol-system that is used to come to terms with these experiences. The religious symbolization depends on the religious character of the social construction of reality with which the individual is at home. Thus, the social construction of reality can be in response to a sensed sacred reality and need not be prior to an experience, but only later seen as explicitly sacred (Hood 2006).

We regard transcendence as a necessary, but not sufficient, condition for religion. Transcendence is a central (necessary) condition for religion, because it claims a) that religion is grounded in experiences (which only secondarily are reconstructed in symbols and rituals-which qualify religion as meaning-making); b) that religion is grounded in experiences of distance and departure from the everyday, of interruption of everyday, or being drawn into another "world;" and c) that these experiences of transcendence per se are not divided into natural and supernatural, because these experiences occur in the life-world-and only secondarily are narrated in stories and thus interpreted in different religious symbol-systems. These characteristics indicate that a concept of religion, based on this understanding of transcendence, is particularly open for an inclusion of what we later call "horizontal transcendence."

If we state that transcendence is a necessary, but not sufficient definitional characterization of religion, we need to say in what way it is not sufficient. Interpreting religion as based upon experiences of transcendence, does not say anything about the importance or centrality of these experiences and their symbolic reconstruction for the individual. In principle, such experiences could be marginal, occasional and insignificant for the life of the individual. But there is another, and perhaps more serious, definitional insufficiency and need for precision: What defines a symbolization as "religious" symbolization? If it is not simply the experience of transcendence per se, then another criterion is required. Instead of referring to the variety of substantive and functional criteria, we suggest an elementary alternative: Tillich's conceptualization of religion. His notion of ultimacy helps to identify the symbolization of experiences of transcending that are not simply important, but ultimately important for the individual, because they respond to ultimate questions and refer to an ultimate environment. In Dynamics of Faith, we read:

(C) Equinox Publishing Ltd. 2013

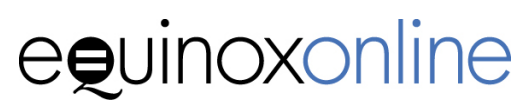


Faith is the state of being ultimately concerned: the dynamics of faith are the dynamics of man's ultimate concern. Man, like every living being, is concerned about many things, above all about those which condition his very existence, such as food and shelter. But man, in contrast to other living beings, has spiritual concerns-cognitive, aesthetic, social, political. Some of them are urgent, often extremely urgent, and each of them as well as the vital concerns can claim ultimacy for a human life or the life of a social group. [...] If faith is the state of being ultimately concerned, all preliminary concerns are subject to it. The ultimate concern gives depth, direction and unity to all other concerns and, with them, to the whole personality.

(Tillich 1957, 105)

Tillich, as we see in this quotation, claims a kind of hierarchical order of concerns. Thus, "(W)hat concerns one ultimately becomes holy" (12f). Tillich links ultimate concern with the holy, but interestingly enough, in a verb-like formulation: they become holy. This is consistent with Tillich's view that also totally this-worldly concerns can become ultimate and holy, such as success, nation or a political leader-which Tillich, from his theological standpoint, qualifies (of course) as "idolatrous faith."

Summarizing our argument so far, in a definition, we may propose that religion is the symbolic and ritual, thus social construction of experiences of "great" transcendences in terms of ultimate concern.

\section{Specific difference A: vertical vs. horizontal}

Combining the concept of transcendence (Schütz; Luckmann) and the concept of ultimacy (Tillich) in a definition of religion has a great advantage in regard to a more inclusive, somewhat broader, but still precise understanding of religion. This understanding of religion is open to, but does not require, an exclusive directedness towards a heaven or a "world above," with divine beings or supernatural agents-however the individual may envision this other world in substantive terms. But it is also open to the possibility that symbolizations of transcendences and ultimate concern are directed toward things, causes or concerns within and part of this world. Thus on the basis of our understanding of religion we may distinguish between a vertical and a horizontal symbolization of transcendence and ultimate concern.

The distinction between vertical and horizontal transcendence has been proposed by Hood et al. (2009, e.g. 282, 286); it is meant to prevent the misunderstanding of people who are not religiously affiliated, or identify with non-theism, agnosticism or humanism, but who explicitly self-iden-

(C) Equinox Publishing Ltd. 2013

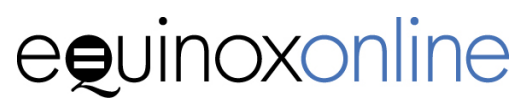


tify as "spiritual," or are committed to a variant of religion which we may call "implicit religion."

Thus the distinction between vertical and horizontal reflects the distinction between implicit and explicit religion. The concept of implicit religion is highly important for the analysis of contemporary religions in cultures such as in America and Europe. This has been demonstrated by E. Bailey's $(1997 ; 2002)$ studies. An elaborate conceptualization of implicit religion has been proposed by G. Thomas (2001), which in turn owes much to F.-X. Kaufmann's (1989) poly-thetic, but primarily functionalist understanding of religion. In Thomas' (2001) study, the "implicit" is considered a derivative of the "explicit." The distinction between vertical and horizontal however regards both as equal, and avoids such primary-secondary hierarchy. Nevertheless, for our mapping of the religious field, the concept of implicit religion plays an important role, because it suggests identifying forms of religion which feature a horizontal symbolization of transcendence and ultimacy and usually are not regarded as religion.

Interesting here is Pasquale's (2007) identification of (what he calls) "non-transcendentalist," self-identifying "spiritual" people in the North West of the US. There is also some parallel of horizontal transcendence with what Taylor (2007, e.g. 726) calls "immanent transcendence." The vertical-horizontal distinction allows us to interpret transcendences and concerns in this world as religion.

The distinction between vertical and horizontal transcendence and ultimacy suggests including those segments in the religious field which previously have been (mis-) understood as non-religious and outside the religious field. What we now label "horizontal transcendence and ultimacy" has been lumped together with the "secular," with "unbelief" or "exclusion of transcendence," ${ }^{1}$ and thus has not been regarded as religious. Our concept of horizontal transcendence allows us to include those types of experiences, attitudes and concerns as (implicit) religion, which qualify as "great" transcendences and have become the ultimate concern. This kind

1. Here we see one of the shortcomings of the conceptual model on which the Post-Critical Belief Scale (Hutsebaut 1996; Duriez, Fontaine and Hutsebaut 2000; Fontaine, Duriez, Luyten and Hutsebaut 2003; Duriez, Soenens and Hutsebaut 2005) is based. The PCBS is not responsive to horizontal transcendence, but is based on Wulff's $(1997,635)$ problematic polarization between inclusion of transcendence and exclusion of transcendence. In this polarization it is presupposed as taken-for-granted what transcendence means-a kind of taken-for-granted normativity that stands also behind the distinction between belief and unbelief.

(C) Equinox Publishing Ltd. 2013

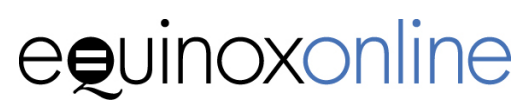


of implicit religion applies to those persons who may identify themselves as "spiritual but not religious," or as "more spiritual than religious" (Hood 2003; Streib et al. 2009).

The distinction between vertical and horizontal could constitute one dimension of the religious field. Table 1 visualizes this dimension as axis $y$, the horizontal vs. vertical axis. To describe the endpoints on the vertical and horizontal axis: Vertical transcendence and ultimacy is characterized a) by the social reconstruction of experiences of "great" transcendences in otherworldly symbols, and b) by a direction of ultimate concern to a supernatural world; the most common symbol here is "heaven" with God, or gods or other divine beings. Horizontal transcendence and ultimacy is characterized a) by the social reconstruction of experiences of "great" transcendences in this-worldly symbols, e.g. as "generalized entanglement," ${ }^{2}$ or in metaphors of wholeness, and b) by a direction of ultimate concern to the sanctity and the creative potential of life, including the individual person, humanity, or nature.

The distinction between vertical and horizontal transcendence and ultimate concern is however not an either-or division. Vertical and horizontal can occur in combination and there may be even some kind of middle ground. The reason for this is obvious: the way of coming to terms with and communicating experiences of transcendence depends on the variety of symbol systems that are available and alive in a specific culture. And symbol systems are changing-which is perhaps the major factor of change in the religious fields in America and Europe.

For a characterization of the middle ground between horizontal and vertical transcendence and ultimacy, we refer to the distinction between theistic and non-theistic. There is a broad variety of non-theistic symbolizations in established religious traditions as well as new religious movements and charismatic groups: for example animistic, pantheistic, spiritualistic or esoteric ${ }^{3}$ symbolizations. Here the direction of transcendence and ultimate

2. Walach and colleagues $(2009,275)$ define spirituality as the relation of the individual to the whole - a relation which includes experience, motivation and action. In order to understand spirituality, Walach and colleagues propose a model of "generalized entanglement" which is related to quantum theory. They understand generalized entanglement as "a formal and scientific way of explaining spirituality as alignment of an individual with a whole, which, according to the model, inevitably leads to non-local correlations."

3. Faivre $(2010,12)$ characterizes esotericism as follows: "The four fundamental characterstics are as follows: 1 . The idea of universal correspondences. Non-"causal" correspondences operate between all the levels of the universe. 2. The idea of living Nature.

(C) Equinox Publishing Ltd. 2013

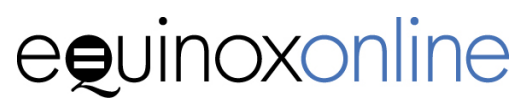


concern is not necessarily vertical in the sense of a clear and primary concern with a heaven, complete with God(s) or divine beings; but it is not simply horizontal either, since an "other world" or realm is not denied. In many instances there is the imagination of a world "behind," as residence for the dead, ghosts, angels, supernatural helpers or simply cosmic energy. It is very likely that people with this kind of middle ground between vertical and horizontal transcendence may be hesitant to self-identify as "religious," but-even if it is only because of the lack of alternatives-they self-identify rather as "spiritual." Thereby "spirituality" refers to a "world behind" and not simply to the (perhaps not yet discovered or acknowledged) relations within nature, as for example is assumed in "generalized entanglement." Table 1 illustrates vertical and horizontal transcendences, but accounting also for this middle ground in form of the middle row.

\section{Specific difference B: institutional mediation vs. individual mediation}

Individualization has become one of the most influential characterizations of modern religious culture in Western societies. It assumes that experiences, beliefs and practices, which for centuries have been embedded in, mediated through, and controlled by, religious institutions, have increasingly become the private affair of individuals. We may talk about a process of deinstitutionalization of religion (Hood et al. 2009, 372-380; Streib 2007).

Luckmann, together with Berger (Berger and Luckmann 1966; Berger 1967; 1979), described individualism as a major transition in modern cultures, heavily influencing also the religious domain (Luckmann 1963; 1967). It is Luckmann's argument that religion has not disappeared in modernity, but that religion has changed its form: it moved from institutional dependency to individual autonomy and individual preference. Therefore Luckmann talks about "invisible religion"-which claims that part of religion has become invisible on the screens of sociologists who primarily attend to institutionalized and organized phenomena. Of course, such expertise is possible only because Luckmann's rather wide concept of religion

The cosmos is not only a series of correspondences. Permeated with invisible but active forces, the whole of Nature, considered as a living organism, as a person, as a history, connected with that of the human being and of the divine world. 3 . The role of mediations and of the imagination. These two notions are mutually complementary. 4. The experience of transmutation.... It is the transformation of oneself, which can be a "second birth"; and as a corollary of a part of Nature (e.g., in a number of alchemical texts).”

(C) Equinox Publishing Ltd. 2013

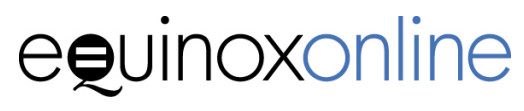


includes a primary focus on individual experiences of transcendences and communicative reconstructions which eventually remain purely individual.

Berger (1979) perhaps went one step further, when introducing the notion of a "heretical imperative" which suggests that persons in modern Western societies have to make an individual choice about their religious preference and affiliation. ${ }^{4}$ Of course, this does not exclude the possibility that people make a choice in favor of their institutional affiliation, that they subject themselves to institutional authority, because they prefer a strong frame of reference. But Berger proposed three options for religious thought: reassertion of authority and tradition (deductive option), interpretation of the tradition in terms of modern secularity (reductive option), and the resort to experience as ground of religious affirmations (inductive option). In these options, we can discern the polarity between institutional mediation vs. individual mediation - which will become the second dimension for our construction of the religious field.

It is the merit of $\mathrm{E}$. Troeltsch to have described religious individualism decades earlier-however not as a new phenomenon in the contemporary religious landscape of his time, but as a type of religiosity that has been around for centuries: mysticism. Troeltsch, in the second volume of his Social Teachings of the Christian Church (Troeltsch 1912), has dealt extensively with mysticism. Interestingly, Troeltsch's terms are "mysticism" and "spiritual religion." His definition of mysticism in "the widest sense of the word" is this: mysticism "is simply the insistence upon a direct inward and present religious experience" (Troeltsch 1912, 730). Mysticism "expresses itself in ecstasy and frenzy, in visions and hallucinations, in subjective religious experience and 'inwardness,' in concentration upon the purely interior and emotional side of religious experience" (Troeltsch 1912, 731). With its "immediacy of feeling," Troeltsch $(1912,731)$ says, mysticism develops "a certain hostility to popular religion and its average forms of expression." Thus in his historical analysis and portrait of mysticism, Troeltsch presents a clear polarity between individual immediacy and institutional mediation. But more: this polarity is presented as a frequent, and rather inevitable, development in the history of religion.

4. Results from our study of deconversion (Streib, Hood, Keller, Csöff, and Silver 2009) even suggests that this choice does not have to be a once-in-a lifetime decision, but there are multiple deconversions and conversions possible. This is consistent with a vast empirical literature on conversion, spiritual transformation, and deconversion (Hood et al., 2009, Ch. 8).

(C) Equinox Publishing Ltd. 2013

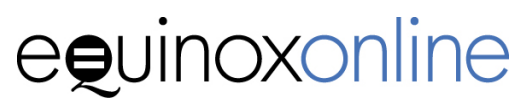


It is important in regard to our construction of the religious field that Troeltsch also accounts for a type of mysticism outside organized religion. Troeltsch indicates a clear difference between the mysticism that dwells and remains inside the Christian tradition, on the one hand, and what Parsons $(1999,141)$ has called "unchurched mysticism," on the other hand. Troeltsch $(1912,743)$ identifies a mysticism that has become independent in principle from, and is contrasted with, churched religion:

The active energies in mysticism of this kind can become independent in principle, contrasted with concrete religion; they then break away from it and set up a theory of their own which takes the place of the concrete religion and of its mythos or doctrine; this may take place either by means of open denial, or through an allegorical change in interpretation. When this takes place, however, mysticism realizes that it is an independent religious principle; it sees itself as the real universal heart of all religion, of which the various myth-forms are merely the outer garment.

For this type of mysticism, Troeltsch $(1912,734)$ maintains that "it feels independent of all institutional religion, and possesses an entire inward certainty, which makes it indifferent towards every kind of religious fellowship." This is what many today profess to be "spirituality," as opposed to "religion." It is essentially an unchurched mysticism.

The problem with Troeltsch's expertise may be that he talks about mysticism primarily in Christianity as it emerged historically. But his identification of religious individualism, including mysticism as a third ideal type, was thoughtful and perhaps ahead of his time (Hood and Chen 2013). We witness today a global spread of just this kind of religious individualism.

Taken together, Troeltsch's detailed historical analysis of mysticism, Luckmann's analysis of invisible religion, and Berger's heretical imperative describe the emergence of an experience-based individual religiosity which is not embedded in religious organizations and does not need, and perhaps does not even accept, any institutional mediation. Thus we think it is justified to construct a second specific difference for our conceptualization of religion, in order to account for an important differentiation in the religious field: that between individual mediation and institutional mediation. To characterize both poles of the polarity: Institutionalized mediation says that, for the individual, there is no other way to transcendence but through the church, the sacraments and priests; that there is no other truth than the institutionally sanctioned teachings; and that the ultimate concern is determined by the institution and its tradition. Consistently, institutional mediation requires religious institutions or organization

(C) Equinox Publishing Ltd. 2013

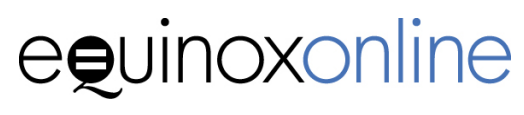


with a high degree of organization and an established wealth of resources. At the other pole of the spectrum, there is no or very low mediation of transcendence, but instead the experiential immediacy of the individual; there are no claims of absoluteness, but individualistic evidence based on experience; there is also no or very low degree of organizational structure. It is the kind of religion that we (Streib and Hood 2001) have called the "privatized, experience-oriented religion."

Following the expertise of Weber and Bourdieu, we conceptualize also here a middle ground, a third option. This third way of mediation is labeled charismatic, and so reflects the sect type of mediation through a prophetic and charismatic person. Readers familiar with the sociological tradition of Weber, Troeltsch and Bourdieu immediately understand that this reflects the differentiation of three types of actors in the religious field, between a) church/priest, b) sect/prophet, and c) magician or mystic. This will be explained in more detail in the next section.

\section{Modeling the religious field}

\section{The legacy of the classics}

The basic pattern for a model of the religious field is the distinction between church and sect, as we derive it from the sociological expertise of Weber and Troeltsch. ${ }^{5}$ The church-sect distinction has become one of the basic tools for understanding religion in sociological terms and for constructing the religious field. This distinction plays a role also in the sociology of new religious movements - even though the terminology has changed, as we avoid the term "sect," in favor of "new religious movements."

Taking a closer look into Weber's work, especially in his analyses in Wirtschaft und Gesellschaft (Weber 1921), we find a distinction, not between two, but between three actors. Not only the sects with their prophets compete with the churches and their priests; the third party is the magicians. What has been widely ignored, but is therefore all the more necessary to recall (Daiber 2002, 329), is that Troeltsch $(1911 ; 1912)$ also talks about three types, but called this third type mysticism. ${ }^{6}$ Troeltsch was clearly using an

5. See the Verhandlungen des Ersten Deutschen Soziologentages October 19-22, 1910 in Frankfurt a. M. (Simmel 1911).

6. Troeltsch's mystic of course is different from Weber's magician. The magician is characterized by Weber as a practitioner of magic coercion, a "small independent entrepreneur hired by private individuals on an ad hoc basis and exercising his office outside any recognized institution, most often in clandestine manner," as Bourdieu $(1987,134)$ summarizes Weber's perspective.

(C) Equinox Publishing Ltd. 2013

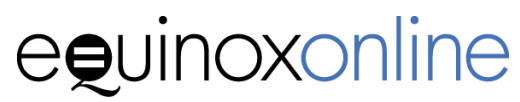


expanded typology, derived from Weber in which, besides church and sect as forms of religious organization, he identified mysticism as the third typean expertise which has been marginalized, especially in the United States. ${ }^{7}$

Bourdieu's (1971) work sets the stage for a sociological analysis of what is called the "religious field." His model of the religious field is close to Weber's in respect to the religious expert actors and their characterization. It is noteworthy that it also includes a third religious expert actor-which, for Bourdieu, in accord with Weber, is the magician. But Bourdieu's special concern has been the dynamic in the (religious) field.

According to Bourdieu, ${ }^{8}$ a field is constituted by the dynamics of competition which follow a field-specific principle (nomos) and field-specific "rules of the game." Thus actors (specialists who best know, and act according to, the rules of the game) compete with each other, and invest and accumulate the specific type of capital which is relevant to the field. They act on the basis of "wealth," i.e. previous achievements, previous accumulation of capital. Thus, in the framework of this rather strict economic model of the field, as presented in Schäfer et al.'s (2008) careful reading of Bourdieu, already the relations with the lay people appear as "external relations." Bourdieu, however, in his $(1971,6)$ sketch of the religious field, has seen the necessity to include the lay people as a fourth pole in the religious field. Bourdieu used two different arrows to indicate the distinction between the kind of relation between the specialist actors and the lay people: specialist actors (church, sect, magician) interact in relations of competition; lay people interact with these religious suppliers in relations of "transactions" or exchange of commodities. This clear increase in value and significance for the lay people may be taken as justification for us to go even one step further, and consider the influence of lay people on the change in the contemporary religious fields.

7. Ironically, Troeltsch was popularized among North American scholars by H. R. Niebuhr, especially in his The Social Sources of Denominationalism (Niebuhr 1929) which was first published in 1929, thus antedating the English translation of Troeltsch's text by 2 years. Niebuhr however dropped Troeltsch's third type, mysticism, so that subsequent theorizing and empirical research on church-sect theory has largely ignored mysticism. The reasons for this are in dispute, but it is clear that neither Niebuhr nor Troeltsch thought well of mysticism and that neither saw it as characteristic of the North American religious landscape (Garrett 1975; Steeman 1975). Whatever the reason, as Garrett $(1975,205)$ has noted, mysticism has experienced "wholehearted neglect" at the hands of sociological investigators.

8. For a comprehensive characterization of Bourdieu's categories in his conceptualization of a "field," see Schäfer, Seibert, Hahne, Tovar and Stockmeier (2008).

(C) Equinox Publishing Ltd. 2013

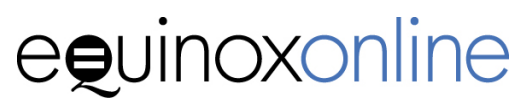


There are more questions than answers in regard to the application of Bourdieu's strict economic model to the religious domain. Several questions are not easy to answer: What exactly is the "nomos" of the religious field? What are the "rules of the game" here? What is "religious capital"? What is the "product," what are the "means of production" in the religious field? Perhaps these questions will be answered in the future and allow for a genuine construction of the religious field in strict Bourdieuian terms. In our construction of the religious fields in Europe and America in order to structure our research and account for the variety of ways of affiliating with and practicing religion, spirituality and related world views, we cannot solve all the open questions in the interpretation of Bourdieu's work. For our purpose, the following characteristics of a "field" are important. There is competition between various religious actors; religious actors compete with each other in attracting lay people as clients; religious actors greatly differ in the degree of achievement and "wealth." But already the "wealth" of a religious actor is difficult to specify: We could take the degree of organization, the number of personnel, the weight of a tradition, its influence in culture and society etc. as indicators. But this can be very low or zero, as in the case of the magicians or mystics, yet nevertheless, magicians and mystics can become serious competitors in the religious field. Thus there must be something else to constitute the "wealth"-in other words: the religious capital - of a religious actor.

The discussion of the concept of religion in part one of this text and our conclusions there may help us to find an answer to the question of religious capital and thus allow us to construct the religious field in a way that does not contradict, but includes, Bourdieu's, Weber's and Troeltsch's expertise. Here is our suggestion: The "wealth" or capital of religious actors is their expertise in transcendence management. This includes: a) Mediation of transcendence, i.e. expertise in the most plausible answers about how to make, cope with, and come to terms with experiences of "great" transcendences, in such a way that the creative potential of the individual profits most; b) Mediation of ultimate concern, i.e. expertise in the most plausible answers to questions of meaning-making, in the supply of the best answers to questions of ultimate concern. This immediately makes clear that a religious actor with no organization, no personnel, no tradition, no claims of institutional mediation, can still hold the most capital and can very successfully compete with established and well-organized religious actors. This may be the reason for the success of "spiritual" actors who are completely un-organized.

(C) Equinox Publishing Ltd. 2013

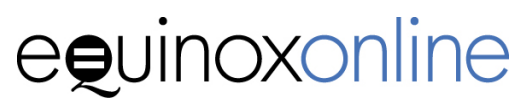




\section{Reconstruction of the religious field}

We thus suggest for the construction of the religious field specific coordinates which take up the thread, but are slightly different, from the classics we have discussed. But this can be justified: The model of the religious field has been designed to account for the dynamics of change in institutionalized religion; its primary focus has been on the religious institutions, on the churches as the established and "wealthy" institutions in the first place, and secondarily on the sects and prophetic movements as serious competitors in the religious field. About the third type of specialist actors in the religious field-whether it is the magician (Weber; Bourdieu) or the mystic (Troeltsch) - there has been uncertainty already in the early sociological discourse regarding their organizational status and sociological relevance.

With reference to a plentitude of studies of contemporary religiosity, we conclude that there is an important - and possibly growing-segment of the religious field which has sociological relevance, but is clearly and radically individualistic, and which features individual immediacy to the transcendent and allows for no authority other than the individual experience-based evidence. Of the three classics, we find most resonance with the detailed and thoughtful analysis of Troeltsch on mysticism. Therefore we find it justified to include all kinds of mysticism and radically individualized religiosity in the religious field and indicate that it is located in a low or un-organized segment of the religious field (we may talk about religious or spiritual scenes, occasional networks), and thus claim for the mystic the status of a full, powerful and eventually wealthy religious actor.

In a second step of reflection, we need to account for the fact that, as detailed above, individuals greatly differ in their understanding of transcendence: there is vertical transcendence and ultimacy and there is horizontal transcendence and ultimacy. But exactly this may constitute the second coordinate for our construction of the religious field. Thus we work with two coordinates in constructing the religious field, which can now be integrated into one model: There are a) differences in the way transcendence is understood and socially reconstructed, differences in the direction of transcendence and ultimacy (vertical and horizontal); there are b) differences in the degree and structure of mediation of transcendence and ultimacy: institutional mediation vs. individual mediation. In Table 1, the ideal types of religious actors are presented. But also the middle-ground variants in both dimensions are accounted for in separate cells. This way,

(C) Equinox Publishing Ltd. 2013

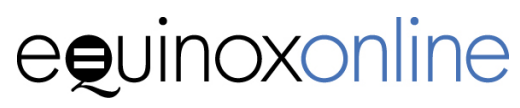


Table 1. Ideal-Types in the American and European Religious Fields Constructed in the Frame of two Coordinates: Symbolization (y) and Mediation (x) of Transcendence and Ultimacy.

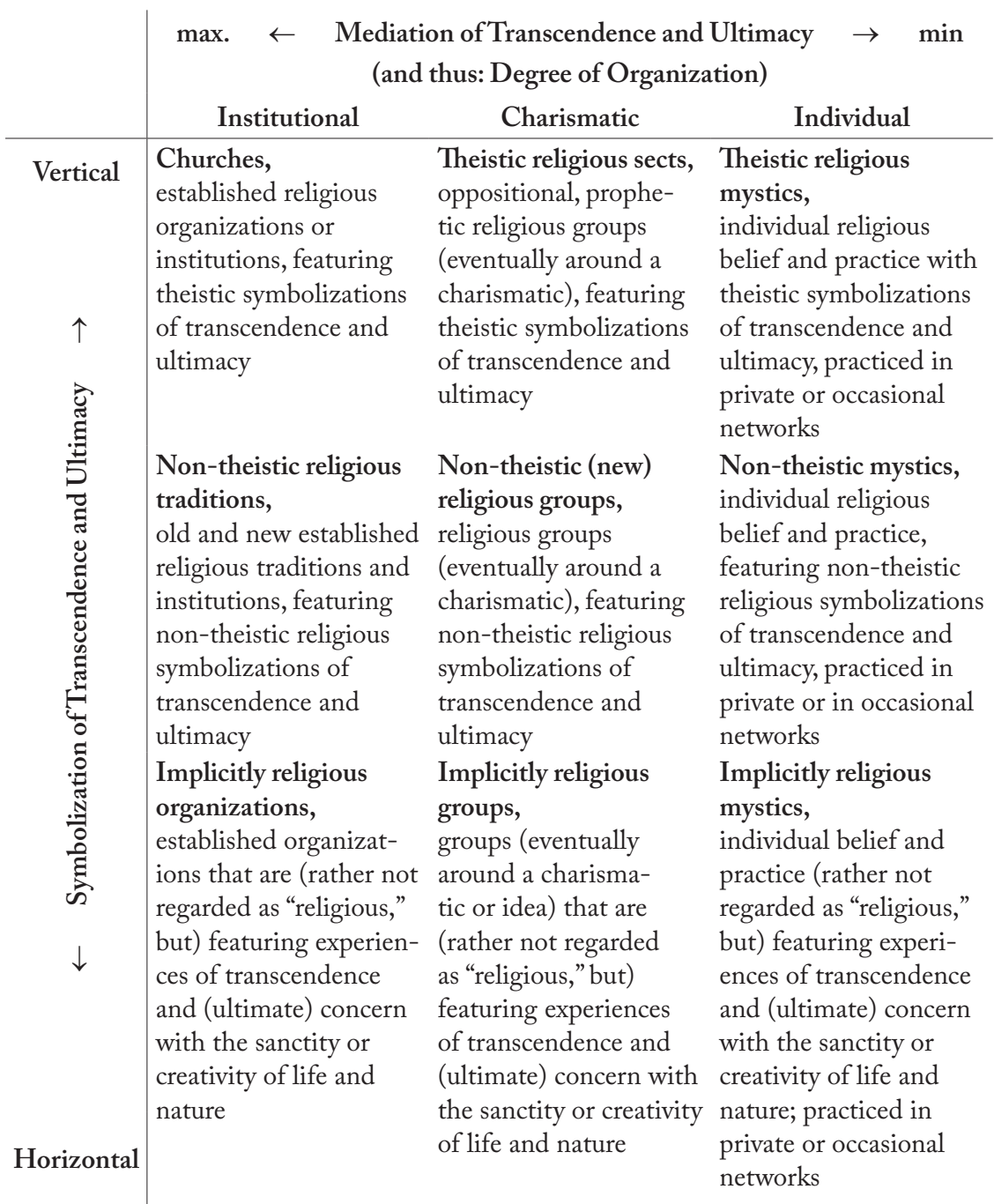

we think, the types of actors in the contemporary implicit and explicit religious fields in America and Europe can be outlined.

We are aware that we suggest a major change in the dimensions of the religious field by the inclusion of horizontal transcendence. As noted already, the type of religiosity featuring horizontal transcendence has

(C) Equinox Publishing Ltd. 2013

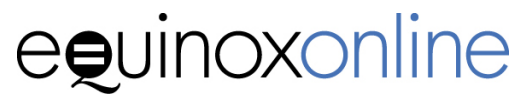


been identified by different terms, "invisible religion" and "implicit religion" among them. We regard this inclusion as absolutely necessary for an adequate understanding of the contemporary religious landscape-and we may be among the first to suggest this inclusion into a religious field model which is derived from the classics. Thus we expect that this model of ideal-type actors in the contemporary religious fields in America and Europe may elicit critical and constructive response, but will also be conceptually helpful for understanding the developments in contemporary religion and, not least, that it stands empirical testing.

\section{References}

Bailey, E. I. 1997. Implicit Religion in Contemporary Society. Kampen: Kok.

- 2002. The Secular Faith Controversy. Religion in Three Dimensions. London : New York: Continuum.

Berger, P. L. 1967. The Sacred Canopy. Elements of a Sociological Theory of Religion. Garden City: Doubleday.

1979. The Heretical Imperative. Contemporary Possibilities of Religious Affirmation. New York: Doubleday.

Berger, P. and T. Luckmann. 1966. The Social Construction of Reality. A Treatise in the Sociology of Knowledge. New York: Doubleday 1989.

Bourdieu, P. 1971. "Une interprétation de la théorie de la religion selon Max Weber [An Interpretation of the Theory of Religion according to Max Weber]." Archives européennes de sociologie 12: 3-21. 1987. "Legitimation and Structured Interest in Weber's Sociology of Religion." In Max Weber, Rationality and Modernity, edited by S. Lash and S. Whimster, 119-136. London: Allen and Unwin.

Daiber, K.-F. 2002. "Mysticism: Troeltsch's Third Type of Religious Collectivities." Social Compass 49: 329-341. http://dx.doi. org/10.1177/0037768602049003002

Duriez, B., J. R. Fontaine and D. Hutsebaut. 2000. "A further elaboration of the post-critical belief scale: Evidence for the existence of four different approaches to religion in Flanders-Belgium.” Psychologica Belgica 40: 153-181.

Duriez, B., B. Soenens and D. Hutsebaut. 2005. "Introducing the Shortened PostCritical Belief Scale." Personality and Individual Differences 38: 851-857. http://dx.doi.org/10.1016/j.paid.2004.06.009

Faivre, A. 2010. Western Esotericism. A Concise History. New York: State University of New York Press.

Fontaine,J.R.J., B.Duriez, P. Luyten and D.Hutsebaut. 2003.“The Internal Structure of the Post-Critical Belief Scale." Personality and Individual Differences 35: 501-518. http://dx.doi.org/10.1016/S0191-8869(02)00213-1

Garrett, W. R. 1975. "Maligned Mysticism: The Maledicted Career of Tro-

(C) Equinox Publishing Ltd. 2013

\section{eevinoxonline}


eltsch's Third Type.” Sociological Analysis 36: 205-223. http://dx.doi. org $/ 10.2307 / 3710366$

Hood, R. W., Jr. 2003. "The Relationship between Religion and Spirituality.” In Defining Religion: Investigating the Boundaries between the Sacred and the Secular: Vol. 10. Religion and the Social Order, edited by A. L. Greil and D. Bromley, 241-265. Amsterdam: Elsevier Science.

2006. "The Common Core Thesis in the Study of Mysticism." In Where God and Science Meet, Vol. 3, edited by P. McNamara, 119-138. Westport, CT: Praeger.

Hood, R. and Z. Chen. 2013. “The Social Sciences and Christian Mysticism.” In Blackwell Companion to Christian Mysticism, edited by J. Lamm, 577-591. Oxford: Oxford University Press.

Hood, R., P. C. Hill and B. Spilka. 2009. The Psychology of Religion: An Empirical Approach (4th ed.). New York: Guilford Press.

Houtman, D. and S. Aupers. 2007. "The Spiritual Turn and Decline of Tradition: The Spread of Post-Christian Spirituality in 14 Western Countries, 1981-2000." Journal for the Scientific Study of Religion 46: 305-320. http:// dx.doi.org/10.1111/j.1468-5906.2007.00360.x

Hutsebaut, D. 1996. "Post-critical Belief: A New Approach to the Religious Attitude Problem." Journal of Empirical Theology 9: 48-66. http://dx.doi. org/10.1163/157092596X00132

James, W. 1902. The Varieties of Religious Experience. Cambridge, MA: Harvard University Press 1985.

Kaufmann, F.-X. 1989. Religion und Modernität. Tübingen: J.C.B.Mohr.

Knoblauch, H. 1991. "Die Verflüchtigung der Religion ins Religiöse [The Evaporation of Religion in the Religious]." In Die unsichtbare Religion, edited by T. Luckmann, 7-41. Frankfurt/M.: Suhrkamp.

Luckmann, T. 1963. Das Problem der Religion in der modernen Gesellschaft. Institution, Person und Weltanschauung [The Problem of Religion in Modern Society. Institution, Person and Worldview]. Freiburg: Rombach.

- 1967. The Invisible Religion. The Problem of Religion in Modern Society. New York: Macmillan.

1991. Die unsichtbare Religion [Invisible Religion]. Frankfurt/M.: Suhrkamp.

Niebuhr, H. R. 1929. The Social Sources of Denominationalism. New York: H. Holt and Company.

Otto, R. 1917. The Idea of the Holy (J. W. Harvey, Trans.). London: Oxford University Press 1958.

Pargament, K. I. 1997. The Psychology of Religion and Coping: Theory, Research, Practice. New York: The Guilford Press.

Parsons, W. B. 1999. The Enigma of the Oceanic Feeling: Revisioning the Psychoanalytic Theory of Mysticism. Oxford: Oxford University Press.

(C) Equinox Publishing Ltd. 2013

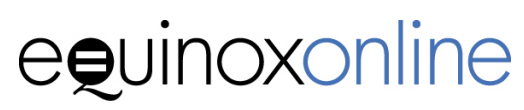


Pasquale, F. L. 2007. The "Nonreligious" in the American Northwest. Online at: http://prog.trincoll.edu/ISSSC/Book/Chapters.asp, retrieved 2008-09-03.

Schäfer, H., L. H. Seibert, P. Hahne, A. Tovar and A. Stockmeier. 2008. Bourdieu's Categories for "Field"-Construction. CIRRuS Working Papers, No.8, Bielefeld. [online at: http://www.uni-bielefeld.de/theologie/CIRRuSdownloads/Schaefer-ea_2009_CIRRuS_field-categories.pdf].

Schütz, A. and T. Luckmann. 1989. The Structures of the Life-World, Vol.2. Evanston: Northwestern University Press.

Simmel, G. (Ed.) 1911. Verhandlungen des Ersten Deutschen Soziologentages vom 19-22. Oktober 1910 in Frankfurt a.M [Discussions of the First German Meeting of Sociologists]. Tübingen: Schriften der Deutschen Gesellschaft für Soziologie, I. Serie, Mohr (Paul Siebeck).

Steeman, T. M. 1975. "Church, Sect, Mysticism, Denomination: Periodical Aspects of Troeltsch's Types.” Sociological Analysis 26: 181-204. http:// dx.doi.org/10.2307/3710365

Streib, H. 2007. Religious Praxis: De-Institutionalized? Theoretical and Empirical Considerations. In Religion inside and outside Traditional Institutions, edited by H. Streib, 147-174. Leiden: Brill. http://dx.doi.org/10.1163/ ej. $9789004157927 . i-322.43$

Streib, H. and R. W. Hood. 2011. “'Spirituality' as Privatized Experience-Oriented Religion: Empirical and Conceptual Perspectives.” Implicit Religion 14: 433-453.

Streib, H., R. W. Hood, B. Keller, R.-M. Csöff and C. Silver. 2009. Deconversion. Qualitative and Quantitative Results from Cross-Cultural Research in Germany and the United States of America. Research in Contemporary Religion, 5. Göttingen: Vandenhoeck and Ruprecht.

Taylor, C. 2007. A Secular Age. Cambridge, MA: Harvard University Press.

Thomas, G. 2001. Implizite Religion. Theoriegeschichtliche und theoretische Untersuchungen zum Problem ibrer Identifikation [Implicit Religion. Theory-historical and Theoretical Investigations to the Problem of the Identification of Implicit Religion]. Würzburg: Ergon.

Tillich, P. 1925. "Religionsphilosophie [Philosophy of Religion]." In Main Works / Hauptwerke, Bd.4, 117-170. Berlin, New York: de Gruyter, Evang.Verlagswerk 1987.

1951. Systematic Theology, Vol. 1. Chicago, IL: University of Chicago Press. 1957. Dynamics of Faith. New York: Harper and Row.

Troeltsch, E. 1911. "Das stoisch-christliche Naturrecht und das moderne profane Naturrecht [The Stoic-Christian Natural Law and the Modern Profane Natural Law].”In Verhandlungen des Ersten Deutschen Soziologentages vom 19-22. Oktober 1910 in Frankfurt a.M., 166-214. Tübingen: Mohr (Paul Siebeck). 1912. The Social Teaching of the Christian Churches, Vol. 2. London, New York: George Allen and Unwin; MacMillan 1956.

(C) Equinox Publishing Ltd. 2013

\section{eevinoxonline}


Walach, H., N. Kohls, N. von Stillfried, T. Hinterberger and S. Schmidt. 2009. "Spirituality: The Legacy of Parapsychology." Archive for the Psychology of Religion / Archiv für Religionspychologie 31: 275-306.

Weber, M. 1921. "Religious Groups (Sociology of Religion).” In Max Weber, Economy and Society, edited by G. Roth and C. Wittich, 399-634. Berkeley, Los Angeles: University of California Press 1978.

Wulff, D. M. 1997. Psychology of Religion. Classic and Contemporary Views (2nd ed.). New York: John Wiley and Sons.

Zinnbauer, B. J. and K.I. Pargament. 2005. "Religiousness and Spirituality." In Handbook of the Psychology of Religion and Spirituality, edited by R. F. Paloutzian and C. L. Park, 21-42. New York, London: The Guilford Press.

Zinnbauer, B. J., K.I Pargament, and A. B. Scott. 1999. "The Emerging Meanings of Religiousness and Spirituality: Problems and Prospects." Journal of Personality 67: 889-919. http://dx.doi.org/10.1111/1467-6494.00077

(C) Equinox Publishing Ltd. 2013 